\title{
Living Law Transplantation in Construction Criminal Medical Law
}

\author{
Juliana Susanti Gunawan \\ Doctoral Program, Faculty of Law, Universitas Andalas. E-mail: julianasusantigunawan71@gmail.com
}

\begin{abstract}
Laws live and develop from patterns of behavior in society, laws are not free of values, between legality and justice are inseparable. Laws made by the authority of sovereign states that are regulated and have sanctions can work effectively if there is a relationship of moral values that provide essential justice. Medical Criminal Law $(\mathrm{MCL})$ regarding medical action has not been comprehensively regulated in the legal subsystem in the health sector. The complexity of the problems that arise in society is always growing which is followed by rapid advances in medical science and technology so that $\mathrm{MCL}$ is needed for legal certainty for medical personnel and legal protection for the community. Literature study in normative analytical research with a conceptual approach offers the idea of moral transplantation in the construction of $\mathrm{MCL}$ can be built under the values that live and develop in society (living law) based on the principle of material legality.
\end{abstract}

Keywords: legal construction; living law; medical criminal.

\section{Introduction}

Good law is a law that has certainty and fair use, the synergy between normative law and law that lives in society (living law) as expressed by Eugen Ehrlich "There would be no law if there were no people who understood the meaning of the law. But, as always, our understanding is formed from the material that we receive from the sensory perception of reality"(Karvatska, 2017: 42). Living law is a law that leads to the future, open to innovation, is a source of normative law. The concept of living law Erlich (1862-1922) was inspired by Carl Von Savigny (1770-1861) with the volkgeist concept of the soul as a source of law "law as an expression of the common consciousness or spirit of the people. Laws are not made but grow and develop together with humans (microcosm) are one with nature (macrocosm). The law is used as the norm for restoring the peace of the cosmos from the chaos so that the law is restitutio in integrum. Law is a reflection of the values prevailing in society, so the design of law for Indonesia is under the cosmology of its plural society which is inseparable from the eastern communal perspective, which is full of traditional beliefs and kinship based on the philosophy and ideology of Pancasila (Sidharta, 2014).

Kant stressed the existence of a human inner value that is reflected in the dignity of humans that governs human will. The law regulates the free will of the man so that it can coexist with the will of other humans to give value to the world (Fasoro, 2019). Ubi societas ibi ius stated by Cicero, show that where there are people there is the law (Salman and Susanto, 2007: 15) and he asked a reflective question: "Would we rather be immersed in pleasure without suffering than to make life more meaningful by helping 
and saving the needy?". Furthermore, in De Finibus Bonorum et Malorum (On the Ends of Goods and Evils), Cicero said that "Everything good is worthy of praise, and everything worthy of praise is moral". Ratio recte vivendi (nobleness of life) is the basis of the correct legal order in the concrete contents of natural law (Owensby, 2020: 19). Moral (Latin: mores) meaning custom, as a truth that lives in a society that influences human values, attitudes, behavior. Reality is inseparable from external influences such as social, cultural, economic, political forces. A dynamic society full of uncertainty and irregularity that Charles Sampford termed as social melee makes legal reality asymmetrical, must also adapt to the full uncertainty and disorder (legal melee). So that reality can be seen as a whole, Sampford with Chaos Theory in Disorder of Law: A Critique of Legal Theory (Sampford, 1989) rejects the assumptions of the Cartesian and Newtonian paradigms and the positivism of science in legal positivism which is dualistic, mechanical, reductionist and determinant which has been formed and influences law enforcement in carrying out the law, which always comes from formal legality without paying substantial attention to the law (Susanto, 2010: 19).

L.M. Friedman, best known for his book The Legal System, A Social Science Perspective (Friedman, 1975), reviews two parts of his previous writings after 40 years of seeing legal developments in a book entitled Impact (Friedman, 2016) that discusses how much social power, law, tradition influence legal system both formally and factually. How much law influences behavior, for example, whether lawsuit rules and cases of doctor negligence can affect the behavior of doctors. How the rule of law can be communicated so that it is understood and implemented by the community. Three factors influence people to obey the rules: first, the existence of rewards and punishment; second, the social context in the form of pressure from the community towards one's expected behavior; third, there is morality that comes from one's mind (inner sense) to do good. Erhard Blankenburg said that there would be a legal paradox if the rules of law were made that were not following the sense of justice and the wishes of the people so that the rules would lead to conflict and even those rules would not be obeyed by the community (Friedman, 2016: 251).

Zhe Liu, senior procurator wrote a book entitled "The case that is working on is about others' life" reminded prosecutors and lawyers to prioritize humanist values and high morality in handling cases because they handled cases that involved a person's life. Court reforms with de bureaucracy and independence of law enforcement in handling cases that are independent of subjective nature or mere formality, look more at the substance of cases by promoting justice and humanity (Cheng and Hu, 2019). The law must meet certain moral standards. Fuller stated that: "when lawmakers fall far short of the ideal of the rule of law, citizens start to feel resentment (Murphy, 2005: 242). If the rule of law is respected, political relations structured by the legal system constitutionally express mutual moral values and respect for autonomy. Lon Fuller stressed that the law must be in line with morality, with eight legal principles: 1. Regulations must be general, 2. Regulations that have been made must be announced, 3. Regulations must not apply retroactively, 4 . Regulations can be understood, 5. Regulations must not contradict each other, 6. Regulations contain demands that can be done, 7. Regulations must not be changed frequently, 8. Regulations must have consistency between those enacted and their daily implementation (Murphy, 2005: 239). 
The community does not obey the rules that are far from morality and a sense of justice, as Doctor Ayu's case began with family prosecution due to the death of Julia Maketey after cito sectio cesaria surgery at R.D. Hospital Kandou Malalayang, Manado, North Sulawesi, on April 10, 2010. Julia's family sued the district court and doctor Ayu was found not guilty with verdict No.90 / Pid.B / 2011 / PN. MDO, appeal, sentenced to 10 months in prison with a verdict Number 365K / Pid / 2012 by using Article 359 of the Indonesian Criminal Code which reads: "Anyone who, due to his mistake (negligence), causes another person to die, is threatened with a maximum imprisonment of five years or a maximum sentence of one year in prison." On Reconsideration, the Supreme Court with a Verdict Number 79 PK / PID / 2013 decided dr. Ayu is innocent (Rizki Akbari, 2015).

The Ayu doctor's case disturbed the solidarity of her professional colleagues in fighting for justice from the decision of the head of the cassation panel: Supreme Court Justice Artidjo Alkotsar, assisted by Dudu Duswara and Sofyan Sitompul as member judges. The decision to convict doctor Ayu was not seen comprehensively, where the judge and prosecutor interpreted the legislation only in text, did not see behind the normative text of the rules there is a moral message there that is a doctor wants to save patients who are threatened with their lives with the highest effort according to his ability, although sometimes these efforts did not achieve optimal results because every medical action there are medical risks that cannot be predicted when it appears. The judge must also consider whether the actions which affect, can previously be known or can be predicted with strong certainty by the offender maker.

Any doctor's actions that do not meet patient expectations or medical actions that cause disability or even death are often associated with malpractice. The term malpractice is unknown in the civil law system adopted by Indonesia, the term is popularized by the mass media and the public uses it as an indictment of doctors to claim material and immaterial damages. Sub-standard medical practices, inadvertent and careless actions that cause injury or death to patients are very difficult to prove due to the absence of normative regulations governing doctor negligence that can be categorized as Unlawful Acts (PMH) (Sibarani, 2020: 31). Medical Criminal Law (MCL) regarding medical actions has not been comprehensively regulated in the legal subsystem in the health sector both in Law number 36 of 2009 concerning Health and Law Number 29 of 2004 concerning Medical Practice so that the legal vacuum regarding $\mathrm{MCL}$ results in the adoption of general criminal code rules contained in the Criminal Code (KUHP).

The Indonesian Medical Association Executive Board (PB IDI) once proposed a Medical Criminal Article to be specifically formulated as a separate article in the Criminal Code Bill (RUU KUHP) as a fulfillment of Human Rights (HAM) and a balance between doctor's rights and patient rights. Medical crimes cannot be equated with general criminal acts, there must be conditions that must be met such as there are elements of mistakes committed intentionally, ability to be responsible, carried out without competence, violating written standards such as professional standards and operational procedure standards, the neglect (omission) medical, is there a medical risk, is there a forgiving factor and justification, is there a medical procedure that is detrimental to the patient to be repeated (IDI, 2019). 


\section{Methods.}

The explanation above has implications for legal issues, the construction of a Medical Criminal Law in Indonesia with a synergy of living law in the community that contains moral values as an element of material legality aimed at the protection (social defense) and social welfare, all components in health services. Analytical normative writing with a conceptual approach, which is obtained from the search of literature studies and analyzed qualitatively, will answer this problem (Soetandyo, 2002: 147).

\section{Results and Discussions.}

\section{Medical Practice}

Health is an essential human right as an element of welfare that must be realized by the state. The government is obliged to provide health services to the public by the mandate of article $28 \mathrm{H}$ paragraph (1) of the 1945 Constitution which guarantees that every person has the right to live in prosperity by obtaining health services. Efforts to realize optimal health degrees are carried out through medical practices carried out by doctors as a major component of health services in the field of Human Resources for Health in Health Care Facilities (Fasyankes).

Data from the Ministry of Health as of December 31, 2019, there were 107,007 doctors employed at the Fasyankes out of 28,754 total Fasyankes in Indonesia, meaning that in one Fasyankes they were only served by an average of three doctors (Kemkes, 2020). Puskesmas without doctors is 12 percent in 2020. The ratio of doctors per 100,000 population has exceeded the target of 50 doctors per 100,000, but there is a considerable disparity between provinces in Indonesia where the highest doctor ratio is in big cities like DKI, Yogyakarta, Bali (Rakerkesnas Kemkes, 2020).

A doctor's job is called a profession because it fulfills the rules of professionalism: having medical knowledge gained during education at the medical faculty, professional ties to the IDI, the professional code of ethics, the Indonesian Medical Ethics Code (KODEKI). Article 1 point 11 of the Medical Practice Law states that: "The medical profession is a medical work that is carried out based on knowledge, competencies obtained through tiered education and a code of ethics that is serving the community. Medical practice is based on scientific value, benefits, fairness, humanity, balance, and patient protection and safety".

Medical practice regulation in the Medical Practice Law aims to provide legal certainty, protection for patients and doctors also quality medical services under Professional Standards, Operational Procedure Standards, patient needs, the development of medical science and technology. According to Van der Mijn in Wila (Wila, 2001: 4) a doctor in carrying out his profession always adheres to three general measures:

\section{a. Doctor's Authority}

The ability to influence other parties authorized by those entitled to authorize. Doctors are given authority in carrying out their profession after obtaining a Registration Certificate (STR) and a Practice License (SIP) by Article 29 paragraph (1) and Article 36 of the Medical Practice Law. Authority based on its nature is divided into formal authority 
according to the Law and material authority or authority of expertise obtained through medical education. A professional in carrying out his work must obtain authority such as a surgeon so that the medical actions he undertakes on a patient's body are not classified as acts of mistreatment.

\section{b. Average Ability}

The ability in knowledge, skills, professional attitude. Difficulties in assessing average abilities in Indonesia due to unequal situation in each region such as the ability of doctors working in Papua with minimal equipment with the ability of doctors working in Jakarta with sophisticated equipment and the experience of doctors to practice differently, so that if there are violations the indicator is average ability compared to doctors in the same field as the accused.

\section{c. Accuracy}

Indicators of accuracy are also very difficult to measure so that the accuracy of each doctor is doing the same work in the same situations and conditions. Article 51 letter a, the Medical Practice Law states that: "every doctor in carrying out the medical practice has the obligation to provide medical services by professional standards and operational procedure standards as well as the medical needs of patients".

\section{Relationship of Doctors and Patients in Medical Practice}

The doctor and patient relationship can occur because of the therapeutic contract relationship or because of the law (zaakwarneming), which is obliged to help people in an emergency. The therapeutic contract starts when the patient asks for help from the doctor by coming to the health facility, the doctor performs anamnesis (questions about complaints of illness), physical examination, supporting examination, confirms the diagnosis and determines the therapy or medical action recorded in a medical record. Before taking a medical action, the doctor first explains what action will be taken, the risks, alternative actions, costs, then after the patient understands, the patient may receive (informed consent), reject the action (informed refusal). The action is based on the principle of autonomy or the right to self-determination, the right to get information which is part of the principle of the right to health care.

In general, medical disputes begin with a legal relationship in the form of contractual Informed Consent (IC). This relationship requires both parties to fulfill the principles of trust and good faith in the form of health services (Trisnadi, 2016). Doctor and patient disputes were caused by changes in society affected by globalization and the economy, expectations and reality gaps that were received for users of medical services, differences in perceptions regarding the object of engagement between doctors and patients, miscommunication between doctors and patients (Astuti, 2003).

An effective patient and doctor dialogue using the Shared Model is a decision on the medical action involving the patient after the patient is given information about the medical action to be performed (Sufa and Widiarto, 2018). Patient dissatisfaction with treatment results, incomplete medical information, being delivered late, or even misinforming so that the impact on medical actions taken also worsens the patient doctor's relationship (Ali, 2006: 16). Doctors rarely ask patients about their opinions while 
patients want to get more information from the doctor. Most disputes are caused by the communication and behavior of doctors (Wool, 2005: 363). Patient service time is less than fifteen minutes because the ratio of the patient's doctor is unbalanced, resulting in an increase in patient waiting time for services that is more than 60 minutes so that the level of patient satisfaction decreases. The shift in patient-physician relationships from paternalistic to partnership requires doctors to minimize communication gaps by providing adequate information on medical or treatment actions to be provided to patients and involving patients more in making decisions. Eastern culture requires communication that is a partnership with caring attitudes communication given by doctors will affect the outcome of patient treatment. There are three barriers to the most communication problems: time is not proportional to the number of patients examined, a communication gap that is influenced by the level of patient education and communication techniques of doctors (Claramita, 2011).

Doctors can avoid conflicts and cooperation with patients by reducing information gaps between doctors and patients, improving trust by treating patients rationally, providing honest information, making sure patients comply with doctor's advice, reducing moral violence between doctors and patients by always evaluating the diagnosis and the provision of therapy so that a harmonious relationship is developed and a healthy relationship between doctor and patient (Lie et al, 2020). Prospective doctors must receive communication training, research on 183 internships with learning through software, shows improved quality of communication between doctor and patient. Jolly and her colleagues also made observations in the Medical Protection Society (MPS) community which provided communication training for doctors in the Risk Management and Communication Masterclass (RMCM) program. The results show improved patientbased communication skills such as empathy, helping patients make decisions, understanding patient expectations, which has an impact on patient satisfaction so that the number of prosecution events is reduced (Joli, et al, 2019). Wu et al (2020) conducted a study from January 1, 2000, to December 31, 2014, 436 cases of criminal malpractice, 70 percent were caused by performance errors, surgeons with cases of sepsis, the most frequent surgical complications causing criminal malpractice. The time needed from the entry of the case to the decision of the law which has an average permanent power of 6.22 years.

\section{National Criminal Law System}

The National Criminal Law System (NCLS) in the future as ius constituendum rests on national identity by adjusting itself to international community relations, prioritizing preventive aspects and paying attention to the principle of ultimum remedium, prioritizing the principle of deliberation and consensus-based on Pancasila to deliver the order of criminal law as a just law and can be used effectively and efficiently. The use of criminal law as an outcome must consider the costs and benefits of the efficiency of the operation of criminal law not only from the legal certainty so that public welfare can be realized (Romli, 2018: 199). If the punishment cannot bring greater benefits to the victim, the defendant, the public then the sentence does not need to be handed down. Utilization according to Bentham in his adage "the greater happiness for the greatest number" says human actions aim to produce benefits, positive effects, pleasure, goodness, happiness, 
prevent the opposite of events such as suffering, threats, unhappiness.

The renewal of the national criminal law as a reflection of a pluralistic democratic state based on Pancasila creates an atmosphere of responsible law with a family spirit based on the principle of consensus towards a just and prosperous society. The goal of the formation of the Indonesian state contained in the fourth paragraph Opening of the 1945 Constitution of the Republic of Indonesia (UUD1945) contains elements of community protection (social defense) and social welfare is the cornerstone of the reform or development of the criminal law system. Renewal and development of the criminal system include the legal system: the legal substance consisting of formal criminal law contained in the Criminal Procedure Code (KUHAP) and material criminal originating from the Criminal Code (KUHP) and the Law outside of the Criminal Code, the legal structure consisting of institutions and facilities and infrastructure supporting the criminal justice system, the legal culture incarnated in legal awareness, legal observance and legal behavior.

\section{Medical Criminal Law}

The category of a crime in the provisions of the Criminal Code if the negligence of an act of medical services is done intentionally. The provisions of the Medical Practice Law regulate the implementation of criminal provisions concerning the requirements for implementing medical practices by doctors, Law No. 36 of 2009 concerning Health acts that are categorized as criminal acts are acts that are carried out with errors in the form of intentional or negligent acts, with a practice license and a permit for the production of medical equipment. Provisions of Law No. 44 of 2009 concerning Hospitals that act which are categorized as criminal acts are against the case of a hospital operating permit.

Criminal provisions in the Medical Practice Act still do not provide legal certainty for doctors as providers of health services, especially in medical action. Criminal medicine should only be limited to acts that contain intentional elements and real or severe negligence, apart from these two elements, medical action cannot be made a criminal object. Article 66 Paragraph (3) of the Medical Practice Law which states that: "Complaints as referred to in paragraph (1) and paragraph (2) do not eliminate the right of everyone to report suspected criminal acts to the authorities and / or sue civil damages to the court" resulting in doctors to be very careful in taking a medical action, for fear of the dangers of layered demands in terms of ethics, discipline, law. Settlement of conflicts between doctors and patients can be taken in three ways: the ethical pathway through the Medical Ethics Honorary Council (MKEK) formed by the professional organization of the Indonesian Doctors Association (IDI), discipline through the Indonesian Medical Disciplinary Honorary Council (MKDKI) is an independent institution under the Medical Council Indonesia (KKI) and legal channels divided by civil law, criminal law, and administrative law through litigation and non-litigation (mediation).

Based on data from the Indonesian Doctors Association (PB IDI), the complaints and lawsuits against doctors in Indonesia continue to grow every year. From 2015 to 2018 the number of lawsuits to doctors was one hundred and eleven. In terms of quantity, the number of cases continues to grow so that it becomes an obstacle in medical services for hospital administrators and medical personnel. The number of new complaints cases in 
2020 was received by the Indonesian Medical Disciplinary Honorary Council (MKDKI) 15 cases involving doctors and hospitals from 39 cases that were in the process until April 30, 2020 (KKI, 2020).

The need for special criminal law such as Medical Criminal Law (MCL) to regulate certain legal subjects and / or special criminal acts, and therefore contain provisions and principles that deviate from general criminal law regulations. Material crimes that are regulated by laws outside the KUHP are permissible under Article 103 of the KUHP 9Bambang, 1984: 6). The complexity of the problems that arise in society is always growing which is followed by rapid advances in medical science and technology so that the Law on MCL is indispensable for legal certainty for medical personnel and legal protection for the community.

\section{Morals in Medical Practice}

Four basic moral principles: a. Respecting human dignity (respect for person). First, patient must be treated as a human being who has autonomy (the right to selfdetermination); second, every human being whose autonomy is reduced or lost needs protection. b. Do good (beneficence), in addition to respecting human dignity, doctors must also make sure that the patients they care for maintain their state of health (patient welfare). The meaning of "doing good" means being friendly or helpful, more than just fulfilling an obligation. c. Not harming (non-maleficence), a medical practice must choose the treatment that has the least risk and the greatest benefit. Ancient statement: first, do no harm, it still applies and must be followed. d. Justice, differences in social position, economic level, political views, religion and beliefs, nationality and citizenship, marital status, as well as gender differences must not and cannot change the attitude of doctors towards their patients. There are no other considerations other than the patient's health which is the doctor's main concern. This basic principle also recognizes the interests of the community around patients that must be considered. Good medical services have important elements which include competence, good relations between doctors and patients, and between services, as well as adherence to professional ethics. Competence is a minimum ability in the field of knowledge, skills, and attitudes and professional behavior to be able to carry out activities in the community independently. In carrying out his profession the doctor must always maintain and improve his competence.

\section{Living Law in the Construction of Medical Criminal Law}

$\mathrm{MCL}$ regarding the regulation of medical measures has not been properly regulated either in the KUHP or in the Medical Practice Law. Moral transplantation in the construction of $\mathrm{MCL}$ can be built under living and developing values in society (living law) based on the material legality principles listed in Article 2 paragraph (1) and paragraph (2) of the Draft Criminal Code Book (RUU KUHP). Criminal sanctions can be imposed if there is an Unlawful Act (PMH) or contrary to the law that lives in the community as stated in Article 12 paragraph (2) of the Criminal Code Bill which states that: "To be declared a criminal offense, an act that is threatened with criminal sanctions and / or actions by statutory regulations must be against the law or against the law that lives in the community".

The principle of material legality by using the law that lives in the community is strengthened by the provisions of Article 5 paragraph (1) of the Law Number 48 of 2009 
concerning Judicial Power specifying that: "Constitutional Justices and Judges must explore, follow, and understand the legal values and a sense of justice that lives in society". These articles are the basis for the judge in the process of finding a law (rechtsvinding) in examining and deciding a case. Decisions of judges functioning as judgemade law can be used as a source of law (jurisprudence) for other judges in deciding cases. Three important factors that influence decisions in court and the achievement of justice. The first factor is the importance of correct decisions in judges' judgments in the court, second; the sociohistorical context of the case which must consider the characteristics of history and society. Every case has a community approach so that judges are free from the rigid ties of absolute legal norms that ignore time and place. The third factor is the personality of the judge, although the judge must carry out the law in making decisions, the judge must have a comprehensive personality that is considering written law, the historical and community context, the energy that lives within the legal norms.

\section{Conclusion}

The law that lives in the community (living law) that is dynamic based on the principle of material legality can be used as the construction of HPM that aims to provide community protection (social defense) and social welfare and to fulfill a sense of justice both doctors as health service providers, patients and the community as recipients of health services 
UIRLawReview. 4(2): 59-70

\section{References}

Ali, M. M dkk. 2006. Komunikasi Efektif Dokter-Pasien. Jakarta: Konsil Kedokteran Indonesia.

Andi Sofyan. 2013. Hukum Acara Pidana. Yogyakarta: Rangkang Education.

Anthon F. Susanto. 2005. Semiotika Hukum Dari Dekonstruksi Teks Menuju Progresivitas Makna. Bandung: Refika Aditama.

. 2010. Ilmu Hukum Non-Sistematik Fondasi Filsafat Pengembangan IImu Hukum Indonesia. Yogyakarta: Genta Publishing.

. Menggugat Fondasi Filsafat IImu Hukum Indonesia dalam Butir Butir Pemikiran dalam Hukum Memperingati 70 Tahun Prof. Dr. B. Arief Sidharta, SH. 2011. Bandung: Refika Aditama.

Bambang Poernomo. 1984. Pertumbuhan Hukum Penyimpangan diluar Kodifikasi Hukum Pidana Bina. Jakarta: Aksara.

Barda Nawawi Arif. 2002. Bunga Rampai Kebijakan Hukum Pidana. Bandung: Citra Aditya Bakti.

Charles Sampford. 1989. Disorder of Law: A Critique of Legal Theory. Oxford: Basil Blackwell.

Friedman, L. M. 1975. The Legal System: A Social Science Perspective, Russell Sage Foundation.

Press.

Hiariej, E. O. 2012. Teori dan Hukum Pembuktian. Jakarta: Erlangga.

Guwandi J. 2010. Malpraktek Medik. Jakarta: Balai Penerbit FKUI.

Otje Salman dan Anthon F. Susanto. 2007. Teori Hukum, Mengingat, Mengumpulkan dan Membuka Kembali. Bandung: Refika Aditama.

P.A.F. Lamintang. 1984. Dasar Dasar Hukum Pidana Indonesia. Bandung: Sinar Baru.

Romli Atmasasmita. 2018. Rekonstruksi Asas Tiada Pidana Tanpa Kesalahan. Jakarta: Gramedia Pustaka Utama.

Wignjosoebroto Soetandyo. 2002. Hukum: Paradigma, Metode, dan Dinamika Masalah. Jakarta: Lembaga Studi dan Advokasi Masyarakatm(ELSAM) dan Perkumpulan untuk Pembaruan Hukum Berbasis Masyarakat dan Ekologi (HUMA),.

Wila Chandrawila Supriadi. 2001. Hukum Kedokteran. Bandung: Mandar Maju.

Kitab Undang Undang Hukum Pidana

Kitab Undang Undang Hukum Acara Pidana

Undang Undang Nomor 48 Tahun 2009 Tentang Kekuasaan Kehakiman

Undang Undang Nomor 29 Tahun 2004 Tentang Praktik Kedokteran 
UIRLawReview. 4(2): 59-70

Undang Undang Nomor 36 Tahun 2009 Tentang Kesehatan

Undang Undang Nomor 44 Tahun 2009 Tentang Rumah Sakit

Astuti, E. K. 2003. Hubungan Hukum Antara Dokter dengan Pasien dalam Upaya Pelayanan Medis Di Rumah Sakit. Disertasi. Semarang: Fakultas Hukum Undip

Cheng. L and Hu. X, Zhe Liu. 2019. The Case You're Working on is About Others' Life. Int J Semiot Law 33, https://doi.org/10.1007/s11196-020-09686-w. [Retrieved from June 20, 2020]

Claramita. M, et al. 2011. Doctor-Patient Communication in A Southeast Asian Setting: The Conflict Between Ideal And Reality. Advances in Health Sciences Education, 16(1).

Fasoro, A. S. 2020, Kant on the Dignity of Autonomy and Respect for the Moral Law. Studia Kantiana, 17(3).

Jolly J, Bowie P, Dawson L, et al. 2019. Evaluation Of A Simulation Based Risk Management And Communication Masterclass To Reduce The Risk Of Complaints, Medicolegal And Dentolegal Claims. BMJ Stel 2020, 6:69-75. doi:10.1136/ bmjstel-2018-000392.

Karvatska, S. 2017. Socio Historical Factors of Law Perception in Living Law Concept by Eugen Ehrlich. Ehrlich's Journal, 1.

Kuan Han Wu et al. Medical Liability of Residents in Taiwan Criminal Court: An Analysis of Closed Malpractice Cases. Hindawi Emergency Medicine International Volume 2020, Article ID 7692964, https://doi.org/10.1155/2020/7692964. [Retrieved from June 20, 2020]

Liu, J., Yu, C., Li, C., \& Han, J. 2020. Cooperation or Conflict in Doctor-Patient Relationship? An Analysis From the Perspective of Evolutionary Game. IEEE Access, 8.

Muhtamar.S \& Ashri. M. 2020. Dikotomi Moral dan Hukum sebagai Problem Epistemologis dalam Konstitusi Modern. Jurnal Filsafat, 30(1)

Murphy. C. 2005. Lon Fuller And Moral Value Of The Rule Of Law. Law and Philosophy 24 (3).

Sufa, S. A., \& Widiarto, D. S. 2018. Malapraktik Dalam Tindak Tutur Kesehatan: Kajian Perspektif Komunikasi Antara Dokter Dengan Pasien. Jurnal Riset Komu nikasi, $1(1)$.

Sun, C., Zou, J., Zhao, L. et al. 2020. New Doctor-Patient Communication Learning Software To Help Interns Succeed In Communication Skills, BMC Med Educ 20, 8 https://doi.org/ 10.1186/ s12909-019-1917-z. [Retrieved from June 20, 2020]

Trisnadi, S. 2016. Perlindungan Hukum Profesi Dokter Dalam Penyelesaian Sengketa Medis. Masalah-Masalah Hukum, 45(2).

Wool, M. S. 2005. Teaching And Learning Communication Skills In Medicine (2e). Health Expectations: An International Journal Of Public Participation In Health Care And Health Policy, 8(4).

Owensby, K. B. 2020. Thought on Trial: Forensic rhetoric and philosophical discourse in Cicero's De Finibus. Doctoral dissertation. Duke University. 
UIRLawReview. 4(2): 59-70

Sibarani. S. 2020. Medical Malpractice In The Legal View. Tarumanagara International Conference on the Applications of Social Sciences and Humanities, Atlantis Press.

https://www.hukumonline.com/pusatdata/detail/17797/rancangan-undang-undang2019

http://kki.go.id/index.php/tentangkami/index/1206/1245/1265/1527/30-april-2020.

http://bppsdmk.kemkes.go.id/info_sdmk/info

https://www.kemkes.go.id/resources/download/info-terkini/Rakerkesnas-2020/02

Sideevent/SE_09/Strategi\%20Pemenuhan\%20SDMK\%20(Kapus\%20Rengun).pdf

http://mappifhui.org/wp-content/uploads/2016/02/Anotasi-Putusan-Perkara-KelalaianMenyebabkan Kematian. 